\title{
Isolation of Kojic Acid Producing Mold using Complex Carbon Sources
}

\author{
Ines Dawiyah Suwarjo, Adnina Fithra Azzahra, Herman Suryadi*
}

\section{Ines Dawiyah Suwarjo, Adnina Fithra Azzahra, Herman Suryadi*}

\section{Laboratory of Microbiology and} Biotechnology, Faculty of Pharmacy, Universitas Indonesia, Kampus UI, Depok, 16424, INDONESIA.

\section{Correspondence}

Dr. Herman Suryadi, M. Si., Apt.

Faculty of Pharmacy, Universitas Indonesia, Kampus UI, Depok, 16424, INDONESIA.

Phone no : +62 8121828612

E-mail: hermans001@yahoo.com

\section{History}

- Submission Date: 31-01-2018;

- Review completed: 05-03-2018;

- Accepted Date: 25-08-2018

\section{DOI : 10.5530/pj.2018.6.184}

Article Available online

http://www.phcogj.com/v10/i6

\section{Copyright}

(C) 2018 Phcog.Net. This is an openaccess article distributed under the terms of the Creative Commons Attribution 4.0 International license.

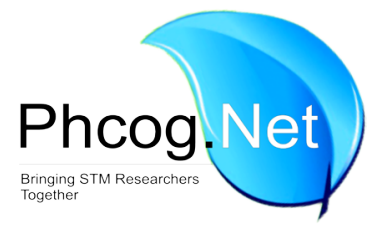

\begin{abstract}
Introduction: An independent effort in term of pharmaceutical raw materials procurement in Indonesia, especially skin brightening agent, is required due to the high demand of brightening skin care product. One of the skin brightening agent widely used in cosmetic skin care formulations is kojic acid. This study aimed to obtain the isolate of kojic acid producing mold from nature and its optimum fermentation condition by using various complex carbon substrates. Methods: Aspergillus oryzae was used as reference. The isolates of fungi were screened with different substrates variation, namely sucrose, corn starch, cassava starch, and cellulose hydrolysate. Then, each of culture was dripped with $\mathrm{FeCl}_{3} 1 \%$ and the most brownish-red color formed was selected as mold and media for further process. The preculture of selected isolate and A. oryzae, were inoculated into $100 \mathrm{ml}$ of fermentation media respectively and incubated at room temperature, 180 RPM for 10 days. The concentration of substrate was varied to $5,7.5$, and $10 \%$. The levels of kojic acid were determined by TLC densitometry with UV detector at $318 \mathrm{~nm}$. Results: IHJ2K isolate in corn starch-yeast extract was selected as the best mold and media. However, the highest level of kojic acid was produced by Aspergillus oryzae with $10 \%$ of substrate, with kojic acid concentration of $5.22 \mathrm{~g} / \mathrm{L}$. The most efficient fermentation was obtained from $A$. oryzae with $7.5 \%$ of substrate, with the obtained yield of $0.53 \mathrm{~g} / \mathrm{g}$. Conclusion: Potential kojic acid producing mold namely IHJ2K was successfully isolated. The selected carbon source for optimum kojic acid fermentation condition with IHJ2K isolate was corn starch combined with yeast extract, $\mathrm{KH}_{2} \mathrm{PO}_{4}$, and $\mathrm{Mg}_{2} \mathrm{SO}_{4} .7 \mathrm{H}_{2} \mathrm{O}$.

Key words: Aspergillus oryzae, Complex carbon, Fermentation, Kojic Acid, Mold, TLC Densitometry.
\end{abstract}

\section{INTRODUCTION}

Skin Care Products are the first Best Cosmetic Sales Prospects in Indonesia, including brightening products. ${ }^{1}$ This fact leads the high demand pharmaceutical raw materials such as brightening agents are required. Unfortunately, $90 \%$ of pharmaceutical raw material in Indonesia are still imported. ${ }^{2}$ Therefore, an independent effort in term of the raw materials procurement in Indonesia's pharmaceutical industry, especially skin brightening agent, is required.

Kojic acid is one of the skin brightening agent widely used in cosmetic skincare formulations. Kojic acid is a major secondary metabolite produced by mold such as Aspergillus and Penicillium species. ${ }^{3-5}$ Glucose, sucrose, acetate, ethanol, arabinose, and xylose have been used as carbon sources for kojic acid production..$^{6-7}$

However, acetate and ethanol may affect the formation of aflatoxin. ${ }^{8}$ Glucose, sucrose, arabinose, and xylose are also expensive to use as raw materials. In this study, an alternative fermentation of kojic acid from selected mold isolates with complex carbon sources was performed. Based on a study by Rosfarizan et al. in 1998, the kojic acid level produced with corn starch compared to glucose as the carbon source was relatively similar. ${ }^{9}$

The aim of this study was to explore further the use of complex carbon such as corn starch, cassava starch, and cellulose hydrolysate as a substrate on kojic acid fermentation. In addition, the isolation of kojic acid producing mold using starch, offers the advantage of reducing the cost of raw materials for the production of kojic acid.

\section{MATERIALS AND METHODS}

\section{Chemicals}

Chemicals used in this study where: potato dextrose agar (PDA) (Difco), yeast extract (Merck), urea $\left(\mathrm{CO}\left(\mathrm{NH}_{2}\right)_{2}\right)($ Merck $)$, ammonium sulphate $\left(\left(\mathrm{NH}_{4}\right)_{2} \mathrm{SO}_{4}\right)$ (Merck), magnesium sulphate $\left(\mathrm{MgSO}_{4} \cdot 7 \mathrm{H}_{2} \mathrm{O}\right)$ (Merck), dikalium phosphate $\left(\mathrm{KH}_{2} \mathrm{PO}_{4}\right)$ (Merck), ferric chloride $\left(\mathrm{FeCl}_{3}\right.$ ) (Merck), orthophosphoric acid(Merck), distilled water, and aquabidest.

\section{Instruments}

The instruments used in this study were autoclave (Hirayama), oven (WTB Binder), analytical balance 
(Acculab), vortex mixer (Barnsted), hotplate stirrer (Corning), $\mathrm{pH}$ meter (Hanna), sentrifugator (Kubota 6800), incubator (Memmert), shaker (Orbit), ose, pipette volume and other glass wares commonly used in laboratories. The analytical instruments used were TLC-Densitometer (Camag TLC Scanner 3) and UV-Vis Spectrophotometer (Shimadzu).

\section{Screening Media}

The media consisted of 5\% variation of carbon sources (sucrose, corn starch, cassava starch, and cellulose hydrolysate, ${ }^{10} 0.5 \%$ variation of nitrogen sources (yeast extract, urea, ammonium sulfate), $0.1 \% \mathrm{KH}_{2} \mathrm{PO}_{4}$ and $0.05 \% \mathrm{MgSO}_{4} .7 \mathrm{H}_{2} \mathrm{O}$. The media was prepared in twelve variations. The $\mathrm{pH}$ of media solution was adjusted to 5 with orthophosphoric acid.

\section{Isolation of Molds}

Molds were isolated from soil and rotten wood. The surface of the soil was cleaned from waste and dirt, then $100 \mathrm{mg}$ of the moist layer beneath was put into the vial. A $100 \mathrm{mg}$ of rotten wood were crushed in a sterile mortar. A hundred milligram of either the soil or the wood was diluted in $10 \mathrm{ml}$ of aquabidest. The soil and wood suspension were diluted until $10^{-9}$ of suspension was obtained.

Both of the suspension were scratched onto potato sucrose agar (PSA) media in a petri dish and incubated at $28^{\circ} \mathrm{C}$ for 5-7 days. Mold colonies grew were isolated based on their morphology. The colony was taken with inoculating loop and scratched onto the new PSA. The new PSA contained colonies was then incubated at $28^{\circ} \mathrm{C}$ for 5-7 days. The ideal colony obtained was transferred to the culture stock tube. The procedure was repeated if the colony obtained had not met the criteria ${ }^{11}$ The purified colonies were transferred to a test tube containing the tilted potato dextrose agar (PDA) media and stored as a culture stock for further test preparation. ${ }^{12}$

\section{Screening of Superior Mold and Media Combination}

The mold colonies seeded on PDA were cultured into 96-wellplates containing a $200 \mu \mathrm{L}$ of screening media, incubated for 6 days at $28^{\circ} \mathrm{C}$. A total of $130 \mu \mathrm{L}$ of supernatant was placed on a drop plate. The screening was done by dripping fresh $\mathrm{FeCl}_{3} 1 \%$.The brownish red color formed was indicated a positive result and the most intense color was selected as the superior mold and media combination..$^{13}$

\section{Macroscopic and Microscopic Identification}

Macroscopic identification was done by observing the colony color, colony diameter, and colony texture. Microscopic identification was performed by examination and observation of mold preparations under a light microscope. Both macroscopic and microscopic observation were compared with Aspergillus oryzae (IPB Culture Collection).

\section{Kojic Acid Fermentation}

The pre-culture of the selected isolate was prepared with $50 \mathrm{~mL}$ of pre-culture media (superior media) in a $100 \mathrm{~mL}$ shake flask. Incubation was carried out by shaking at $180 \mathrm{rpm}, 28^{\circ} \mathrm{C}$ for $48 \mathrm{~h}$. Preparation of inoculum was also performed on Aspergillus oryzae. Fermentation was done with $100 \mathrm{~mL}$ media and $10 \%(\mathrm{v} / \mathrm{v})$ inoculum in $250 \mathrm{~mL}$ shake flask. The level of carbon source was varied to $5,7.5$, and $10 \%$. The flasks were incubated by rotary shaker at $180 \mathrm{rpm}, 28^{\circ} \mathrm{C}$ for 10 days. At the same time, fermentation of Aspergillus oryzae was also performed.

\section{Analytical Methods}

The presence of kojic acid in the culture filtrate was determined using UV-Vis spectrophotometry and colorimetric method, and analyzed quantitatively using TLC-Densitometer (CAMAG III, Switzerland), using silica gel $\mathrm{F}_{254}$ as stationary phase, toluene-ethyl acetate-formic acid (3:6:1) as mobile phase, and UV detector at $318 \mathrm{~nm}$. The calibration curve was made using kojic acid standard solution with a range of 20-80 ppm.
Glucose concentration was determined using DNS method. ${ }^{14}$ Biomass was determined by the dry cell weight method. Culture samples were pipetted into a pre-weighed tubes and centrifuged at 7500 RPM for $15 \mathrm{~min}$. Supernatant was used for kojic acid analysis, while biomass was washed with distilled water, centrifuged, and dried at $105^{\circ} \mathrm{C}$ to a constant weight.

\section{RESULTS AND DISCUSSION}

\section{Isolation of Molds}

Eight colonies were obtained based on the morphology. There were two black-spores colonies surrounded by white mycelia named IHIT (Figure 1.a) and IHIK (Figure 1.b), which secreted yellow pigment underneath. A green colony surrounded by a white mycelia was isolated, which was IHJT (Figure 1.c). A different green colony that secreted yellow pigment underneath was also isolated and was named IHJ1K (Figure 1.d). There was also a yellowish-green colony surrounded by white mycelia named IHJ2K (Figure 1.e), a yellow-green colony isolated from wood, named IHJKK (Figure 1.f), a brownish-green that was isolated from wood called ICK (Figure 1.g), and a brown colony isolated from soil which was named ICT (Figure 1.h).

\section{Screening of Superior Mold and Media Combination}

The IHJ2K (Figure 2.e) and IHJKK (Figure 2.f) were the types of mold which produced an intense brownish color. Re-screening was performed on IHJ2K and IHJKK fermentation after two days. The results showed that $\mathrm{IHJ} 2 \mathrm{~K}$ in media containing $5 \%$ corn starch, $0.5 \%$ yeast extract, $0.1 \%$ $\mathrm{KH}_{2} \mathrm{PO}_{4}$, and $\mathrm{Mg}_{2} \mathrm{SO}_{4} .7 \mathrm{H}_{2} \mathrm{O} 0.05 \%$ yielded the most intense brownishred color (Figure 3.a).

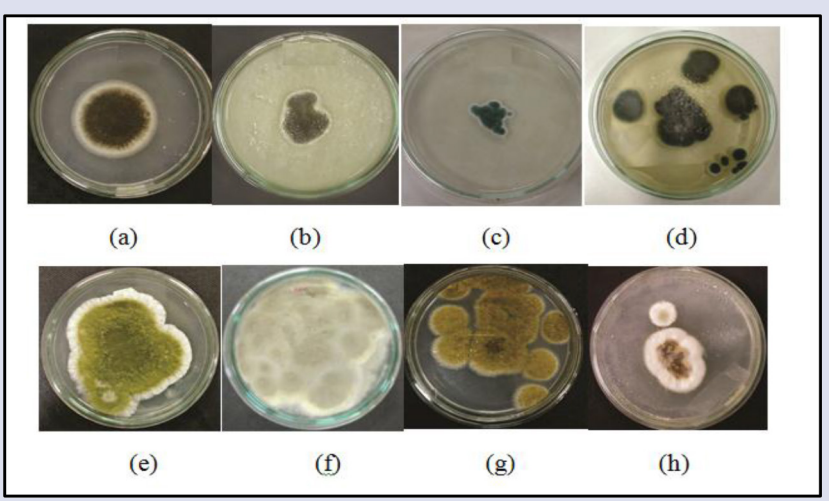

Figure 1: Mold Isolates based on their morphology.

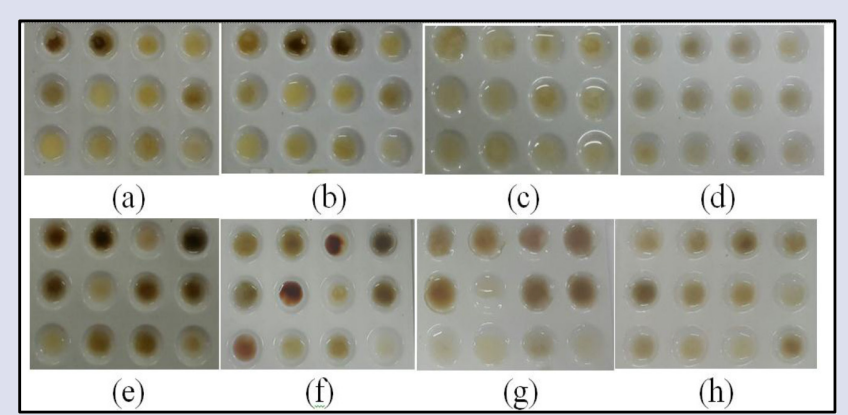

Figure 2: Screening results of $8 \times 12$ culture filtrate. 


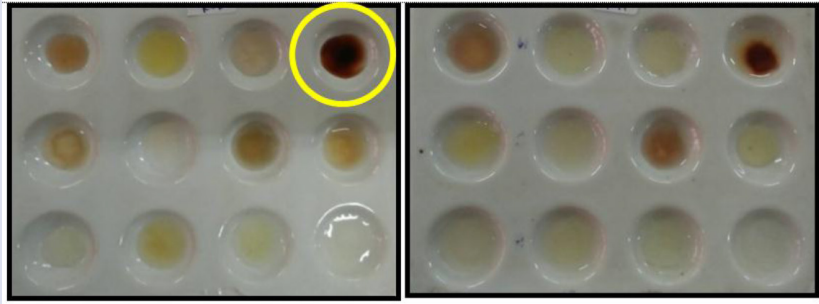

(a)

(b)

Figure 3: Screening results of $\mathrm{IHJ} 2 \mathrm{~K}$ and IHJKK culture filtrate.

The result showed that $\mathrm{IHJ} 2 \mathrm{~K}$ isolate contained amylase, glucoamylase, and other hydrolase enzymes that play a role in the metabolism of starch. Thus, IHJ2K could hydrolyze amylose and amylopectin into glucose, a precursor compound in the kojic acid biosynthetic pathway. ${ }^{15}$ This suggested that IHJ2K was able to produce kojic acid on complex carbon sources in a short time.

Corn starch was selected as a superior carbon source due to its low percentage of amylopectin compared to cassava starch. ${ }^{16}$ The degree of polymerization (DP) of amylopectin ranged from $10^{5}$ to $3 \times 10^{6}$ units of glucose. The more units required to be hydrolyzed on cassava starch the longer time required for kojic acid productivity. Meanwhile, $\beta$-cellulose had lower kojic acid productivity than corn starch due to the presence of cellulose which had not been fully hydrolyzed to glucose. Yeast extract wasalso selected considering its complex structure compared to urea and ammonium sulfate to provide a richer nutritional intake.

\section{Macroscopic and Microscopic Identification}

The macroscopic identification results showed that the growth of IHJ2K on PSA media with temperature of $28^{\circ} \mathrm{C}$ grew to $8 \mathrm{~cm}$ in diameter in 7 days. The colony had a yellowish green color surrounded by white mycelium and velvety texture (Table 1).IHJ2K had the same spores as Aspergillus oryzae. Aspergillus had a type of asexual spore called conidia. ${ }^{17}$

\section{Kojic Acid Fermentation}

The UV spectrophotometric absorption spectra of the kojic acid standard and culture sample (IHJ2K in $10 \%$ corn starch) indicated the same maximum wavelength, which was $268.8 \mathrm{~nm}$.

The spectrocolorymetry absorption spectra of kojic acid standard and culture sample (IHJ2K in $10 \%$ corn starch) also showed the same maximum wavelength at 503,6 $\mathrm{nm}$. This result showed that the IHJ2K culture contained kojic acid.

The biomass produced by IHJ2K was higher compared to A. oryzae. The higher substrate concentration, the higher biomass produced by IHJ2K which could be seen in a pattern (Table 2).Meanwhile, the escalation of A. oryzae's biomass was not as patterned as IHJ2K's. Too much sugar in A. oryzae fermentation enhanced water to escape from biomass cells because of the difference in osmotic pressure between the environment outside the cell and the fluid inside the cell. Thus, the condition affected the cell to be dehydrated resulted in the inhibition of the cell growth. The differences in environmental osmotic pressure outside the could also cause plasmolysis and microorganisms cells death. ${ }^{18}$ It could be concluded that the growth of IHJ2K on the corn starch complex substrate was better than A. oryzae.

The highest kojic acid level was produced by A. oryzae with $10 \%(\mathrm{w} / \mathrm{v})$ of corn starch (Table 2). However, the highest yield was obtained by A. oryzae with $7.5 \%$ of corn starch. The dramatic increase in viscosity of the high concentration of starch could decrease the rate of oxygen transfer
Table 1: Macroscopic and Microscopic Comparison of IHJ2K with Aspergillus oryzae.

\begin{tabular}{ccc}
\hline Mold & Morphology & Microscopy \\
\hline $\begin{array}{c}\text { Aspergillus oryzae } \\
\text { (IPB Culture } \\
\text { Collection) }\end{array}$ & & \\
\hline
\end{tabular}

Table 2: Growth of IHJ2K and A. oryzae and their kojic acid production.

\begin{tabular}{|c|c|c|c|c|c|c|}
\hline Isolate & $\begin{array}{c}\text { Corn } \\
\text { starch } \\
\text { (g/L) }\end{array}$ & $\begin{array}{c}\text { Biomass } \\
(\mathrm{g} / \mathrm{L})\end{array}$ & $\begin{array}{l}\text { Kojic } \\
\text { acid } \\
\text { (g/L) }\end{array}$ & $\begin{array}{c}\text { Glucose } \\
\text { remained } \\
(\mathrm{g} / \mathrm{L})\end{array}$ & $\begin{array}{c}\text { Glucose } \\
\text { consumed } \\
\text { (g/L) }\end{array}$ & Yield $(g / g)$ \\
\hline \multirow{3}{*}{ 总 } & 50 & 17,84 & - & 0,19 & 49,81 & - \\
\hline & 75 & 25,78 & 0,204 & 0,23 & 74,77 & $2,73 \times 10^{-3}$ \\
\hline & 100 & 30,58 & 3,781 & 74,74 & 25,26 & 0,15 \\
\hline \multirow{3}{*}{ 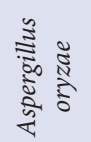 } & 50 & 15,37 & - & 0,22 & 49,78 & - \\
\hline & 75 & 22,13 & 3,158 & 69 & 6 & 0,53 \\
\hline & 100 & 22,23 & 5,22 & 72,74 & 27,26 & 0,19 \\
\hline
\end{tabular}

to culture ${ }^{9}$ leaded to the A. oryzae fermentation in $10 \%$ of corn starch was less efficient. In addition, the more level of corn starch substrate used by IHJ2K, the more the level of kojic acid was produced.

Overall, the yields obtained by IHJ2K fermentation were less than by Aspergillus oryzae. Although the $\mathrm{IHJ} 2 \mathrm{~K}$ isolate showed an increase in kojic acid concentration and its yield by increasing the substrate concentration, but it had not been able to outperform the efficiency of kojic acid productivity resulted by Aspergillus oryzae.

\section{CONCLUSION}

In conclusion, kojic acid producing mold called IHJ2K was successfully isolated. The carbon source for optimum kojic acid fermentation condition with $\mathrm{IHJ} 2 \mathrm{~K}$ isolate was corn starch combined with yeast extract, $\mathrm{KH}_{2} \mathrm{PO}_{4}$, and $\mathrm{Mg}_{2} \mathrm{SO}_{4} .7 \mathrm{H}_{2} \mathrm{O}$.

\section{ACKNOWLEDGEMENT}

The authors are grateful to DRPM Universitas Indonesia for grant "Hibah PITTA 2017" which supporting this study.

\section{CONFLICT OF INTEREST}

The authors are declare that there is no conflict of interest.

\section{ABBREVIATIONS}

TLC: Thin Layer Chromatography; PSA: Potato Sucrose Agar; PDA: Potato Dextrose Agar; UV: Ultraviolet; UV-Vis: Ultraviolet-Visible; DNS: 3.5-dinitro salicylic acid. 


\section{REFERENCES}

1. US Department of Commerce. Cosmetics and toiletries market overviews. 2015:39

2. International Trade Center. Supply and demand survey on pharmaceuticals and natural products - Indonesia. 2006:17.

3. Hazzaa MM, Saad AM, Hassan HM, Ibrahim E. High production of kojic acid crystals by isolated Aspergillus oryzae var. effusus NRC14. J Appl Sci Res. 2013;9(3):1714-23.

4. Bentley R. From miso, sake, and shoyu to cosmetics: A century of science for kojic acid. Nat Prod Reports. 2006;23(6):1046-62.

5. Suryadi H, Radji M, Dianingtyas J, Hidayah A. Improvement of kojic acid production by a mutant isolate of Aspergillus flavus, N40C10. International Conference on Mathematics and Natural Sciences. Bandung. 2006.

6. Kitada M, Ueyama H, Suzuki E, FukumbaraT. Studies on kojic acid fermentation. I cultural condition in submerged culture. J Ferment Technol. 1976;45(12):1101-7.

7. Basappa SC, Sreenivasamurthy V, Parpia H. Aflatoxin and kojic acid production by resting cells of Aspergillus flavus Link. J Gen Microbiol. 1970;61(1):81-6.

8. Wilson BJ. Miscellaneous Aspergillus toxins. In: Ajl S, Kadis S, Ciegler A, editors. Microbial Toxins. New York [etc.]: Academic Press. 1971:235-50.

9. Rosfarizan M, Madihah S, Ariff A. Isolation of a kojic acid-producing fungus capable of using starch as a carbon source. Lett. In Appl Microbiol. 1998;26(1):27-30.
10. Achor M, Oyeniyi YJ, Yahaya A. Extraction and characterization of microcrystalline cellulose obtained from the back of the fruit of Lageriana siceraria (water gourd). J of Appl Pharm. Sci. 2014;4(1):57-60.

11. Suryadi $H$, Radji M, Respati E. Isolasi dan skrining kapang potensial penghasil monakolin k. Sains Indonesia. 2007;12(1):21-5.

12. Ujiani ZD. Identifikasi jamur pendegradasi lignin pada serasah bitti vitex cofassusreinw. dari kabupaten bulukumba. Thesis, Hasanuddin University, Makassar Indonesia. 2009.

13. Sulistyaningrum L. Optimasi fermentasi asam kojat oleh galur mutan Aspergillus flavus NTGA7A4UVE10. Thesis, Faculty of Pharmacy, University of Indonesia, Depok, Indonesia. 2008

14. Oktavia Fl, Argo BD, Lutfi M. Hidrolisis enzimatis ampas tebu (bagasse) memanfaatkan enzim selulase dari mikrofungi Trichoderma reseei dan Aspergillus niger sebagai katalisator dengan pretratment microwave. Thesis, Faculty of Food Technology, Brawijaya University, Depok, Indonesia. 2014;2(3).

15. Chaudary J. Production technology and applications of kojic acid. Ann Res and Rev in Biology. 2014;4(21):3165-96.

16. Martinez JH, Schienmakers $P$, KokW. Determination of the amylose-amylopectin ratio of starches by iodine-affinity capillary electrophoresis. J Chromatog A. 2004;1053(1-2):227-34.

17. Osherov N, May GS. The molecular mechanisms of conidial germination. FEMS Microbiol. Lett. 2001;199(2):153-60.

18. Radji M. Buku Ajar Mikrobiologi. Jakarta: Penerbit Buku Kedokteran EGC. 2011;11-9.

\section{GRAPHICAL ABSTRACT}

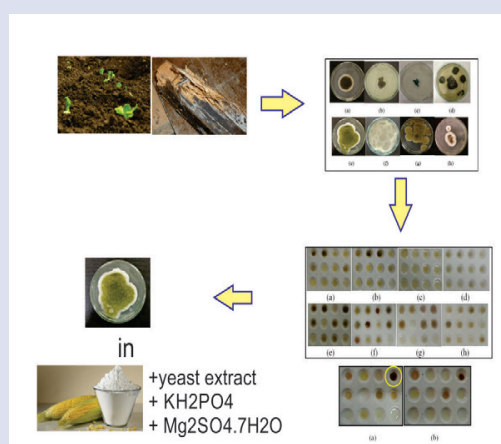

\section{SUMMARY}

- Isolation of molds from soil and rotten wood. Eight colonies were obtained

- Screening of superior mold and media combination in producing kojic acid. A colony called IHJ2K which fermentated in corn starch combined with yeast extract, $\mathrm{KH}_{2} \mathrm{PO}_{4}$, and $\mathrm{Mg}_{2} \mathrm{SO}_{4} \cdot 7 \mathrm{H}_{2} \mathrm{O}$ was selected.

- Identification of the superior mold macroscopically and microscopically

- Qualitative and quantitative analysis of kojic acid

\section{ABOUT AUTHORS}

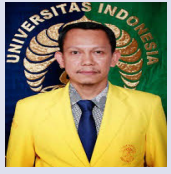

Herman Suryadi, currently working as Head of Laboratory of Microbiology and Biotechnology, Faculty of Pharmacy, Universitas Indonesia. His research focused on Bioprocess, Biotechnology and Pharmaceutical Chemistry.

Cite this article: Suwarjo ID, Azzahra AF, Suryadi H. Isolation of Kojic Acid Producing Mold using Complex Carbon Sources. Pharmacog J. 2018;10(6):1089-92. 